\title{
Sistem Informasi Perpustakaan Pada Madrasah Aliyah Negeri 16 Jakarta Kota Jakarta Barat
}

\author{
Indra Permana Putra ${ }^{1}$, Agus Junaidi ${ }^{2}$, Popon Handayani ${ }^{3}$, Yunita ${ }^{4}$ \\ 1,3,4Program Studi Sistem Informasi, STMIK Nusa Mandiri \\ e-mail: 1indrapermanaputra1611@gmail.com, ${ }^{3}$ popon.pph@nusamandiri.ac.id, \\ 4yunita.yut@nusamandiri.ac.id \\ ${ }^{2}$ Universitas Bina Sarana Informatika \\ e-mail:agus.asj@bsi.ac.id
}

\begin{abstract}
Abstrak
Teknologi Informasi sudah menjadi pilihan utama dalam menciptakan suatu sistem informasi yang dapat memberikan informasi secara tepat dan akurat. Sistem Informasi Perpustakaan di Madrasah Aliyah Negeri 16 Jakarta Kota Jakarta Barat masih menggunakan sistem manual. Sistem ini sudah kurang sesuai dimana peminjaman buku dan pengembalian buku masih menggunakan buku atau kertas dalam bertransaksi, sehingga membutuhkan waktu yang cukup lama dalam melakukan pengelolahan pencatatan data buku peminjaman dan pengembalian. Dari uraian masalah diatas maka diperlukan suatu sistem informasi pengelolahan data perpustakaan pada Madrasah Aliyah Negeri 16 Jakarta Kota Jakarta Barat agar sistem menjadi lebih efisien seperti halnya sistem peminjaman dan pengembalian yang sering bermasalah dan memakan waktu yang lama sehingga membutuhkan perkembangan dengan memanfaatkan teknologi yang ada misalnya menggunakan website dan memudahkan petugas dalam melakukan pencatatan transaksi peminjaman dan pengembalian buku. Metode penelitian yang digunakan dalam penelitian ini adalah metode System Development Life Cycle (SDLC) dengan model Waterfall. Model air terjun (Waterfall) sering juga disebut model sekuensial linier (sequential liniear) atau alur hidup klasik (classic life cycle). Hasilnya sistem informasi perpustakaan ini dapat mempermudah petugas perpustakaan dalam mengelola data perpustakaan serta mempercepat proses pembuatan laporan dengan memilih opsi cetak
\end{abstract}

Kata Kunci : Sistem Informasi; Perpustakaan; Peminjaman dan pengembalian buku

\begin{abstract}
Information Technology has become the main choice in creating an information system that can provide information accurately and accurately. Library Information Systems in Madrasah Aliyah Negeri 16 Jakarta, West Jakarta City still use manual systems. This system is less suitable where borrowing books and returning books still use books or paper in transactions. so that it takes a long time to manage the recording of loan and return book data. From the description of the problem above, we need an information system for managing library data at the Madrasah Aliyah Negeri 16 Jakarta West Jakarta City so that the system becomes more efficient as well as borrowing and returning systems that are often problematic and time consuming so that they need development by using existing technology such as using website and make it easier for officers to record loan transactions and return books. The method used in this research is the System Development Life Cycle (SDLC) with the Waterfall model. The waterfall model (waterfall) is often called the linear sequential model (sequential linear) or classic live groove (classic life cycle). The result is this library information system can facilitate library officers in managing library data and speed up the process of making reports by selecting print options
\end{abstract}

Keywords : Information Systems; Library; Lending and returning books

\section{Pendahuluan}

Madrasah Aliyah Negeri (MAN) 16

Jakarta merupakan salah satu instansi yang menyelenggarakan program pendidikan formal. Untuk mendukung kegiatan belajar mengajar, MAN 16 Jakarta menyediakan perpustakaan yang saat ini dikelola oleh petugas perpustakaan. Sistem Informasi 
pada MAN 16 Jakarta masih menggunakan sistem manual, kendala yang dihadapi adalah kesulitan dalam temu-balik informasi. Sistem yang ada saat ini untuk sistem pencatatan kategori buku, data anggota, peminjaman, pengembalian, dan denda masih dilakukan dengan menulis pada buku besar, sehingga terjadi keterlambatan dalam mencari data yang dibutuhkan (Dari, Sari, \& Astrilyana, 2019) seperti proses pelayanan peminjaman dan pengembalian buku di perpustakaan, untuk menemukan data peminjam dan proses pengolahan data buku di perpustakaan, hal ini dirasakan kurang efektif dan efisien dalam pengelolaan perpustakaan.

Perpustakaan sebagai salah satu bagian dari tempat pendidikan mempunyai peranan yang sangat penting untuk menambah wawasan dan pengetahuan pelajar. Bermacam-macam sumber informasi ilmiah, buku-buku, literatur dari segala jenis media perpustakaan, mampu disebarluaskan dengan sistem tertentu (Nugraha, 2014). Oleh karena itu, untuk meminimalisasi permasalahan yang ada dan membuat pekerjaan menjadi lebih efektif dan efisien harus ada sistem yang terkomputerisasi. Diharapkan pengelolaan perpustakaan menjadi lebih efektif dan efisien, penyajian laporan menjadi lebih akurat dan tepat waktu (Dari et al., 2019). Hal ini juga bertujuan untuk memudahkan pencarian koleksi buku secara cepat dan mudah melalui internet (Sasongko, 2015).

\section{Metode Penelitian}

Metode penelitian yang digunakan dengan melakukan observasi atau studi lapangan dengan melihat secara langsung proses kegiatan Perpustakaan di Madrasah Aliyah Negeri 16 Jakarta. Metode pengembangan sistem yang digunakan adalah SDLC (system Depelopment Life Cycle) dengan model proses waterfall seperti metode yang digunakan penulis lain (Sasongko, 2015), (Rizki Hendramayana \& Junaidi, 2016). Berikut ini adalah tahapantahapannya :

\section{A. Analisis Kebutuhan Sistem}

Kebutuhan-kebutuhan tersebut di dokumentasikan dan di sesuaikan dengan kebutuhan pengguna, pengguna sistem informasi perpustakaan antara lain :

1. Kebutuhan fungsional anggota

Mendaftar sebagai anggota, melihat data

buku, data kategori, data penerbit transaksi peminjaman, transaksi pengembalian.

2. Kebutuhan fungsional administrator sistem

Mengelola data user, data siswa, data kategori, data buku, data penerbit transaksi peminjaman, transaksi pengembalian dan laporan.

\section{B. Desain}

Penulisan ini mulai memikirkan perancangan yang akan dikerjakan, dengan acuan program yang dibuat harus user friendly dan dengan menggunakan metode UML (Unified Modelling Languange) desain data dengan membuat use case diagram, activity diagram, desain database dan ERD. Desain yang akan digunakan adalah untuk memprioritaskan sesuai dengan kebutuhan user. Dengan sistem interaksi yang lebih familiar dan mudah dipahami oleh user dalam penggunaannya.

\section{Code Generation}

Untuk menunjang pembuatan program ini, menggunakan PHP sebagai bahasa pemrograman, software adobe dreamweaver CS6 sebagai editor dan $M y S Q L$ sebagai database XAMPP sebagai database tools.

\section{Testing}

Pada tahap ini pengujian dilakukan pada server local (localhost), dalam pengujian sistem perpustakaan ini penulis menggunakan metode pengujian black-box testing untuk mendeteksi suatu kesalahan (error), agar kesalahan-kesalahan pada aplikasi web yang telah dibuat kemudian dapat diperbaiki.

\section{Hasil dan Pembahasan}

\subsection{Analisa Kebutuhan Sistem}

A. Pada bagian ini admin dapat:

1. Admin dapat login ke halaman admin.

2. Admin dapat mengelola data user.

3. Admin dapat mengelola data penerbit.

4. Admin dapat mengelola data kategori.

5. Admin dapat mengelola data buku.

6. Admin dapat mengelola data anggota.

7. Admin dapat mengelola pengadaan.

8. Admin dapat mengelola data peminjaman dan pengembalian buku.

9. Admin dapat mencetak laporanlaporan.

B. Pada bagian anggota dapat: 
1. Anggota baru melakukan pendaftaran untuk membuat username dan password.

2. Anggota yang sudah memiliki username dapat login.

3. Anggota dapat melihat data penerbit.

4. Anggota dapat melihat data kategori.

5. Anggota dapat melihat daftar buku dan memfilter data buku sesuai kategori.

6. Anggota dapat melakukan transaksi peminjaman buku.

\subsection{Desain}

Dalam penelitian desain sistem informasi perpustakaan ini menggunakan diagram Unified Modeling Language (UML) yang diuraikan kedalam tahapan sebagai berikut :

A. Desain Sistem

1. Use Case Diagram

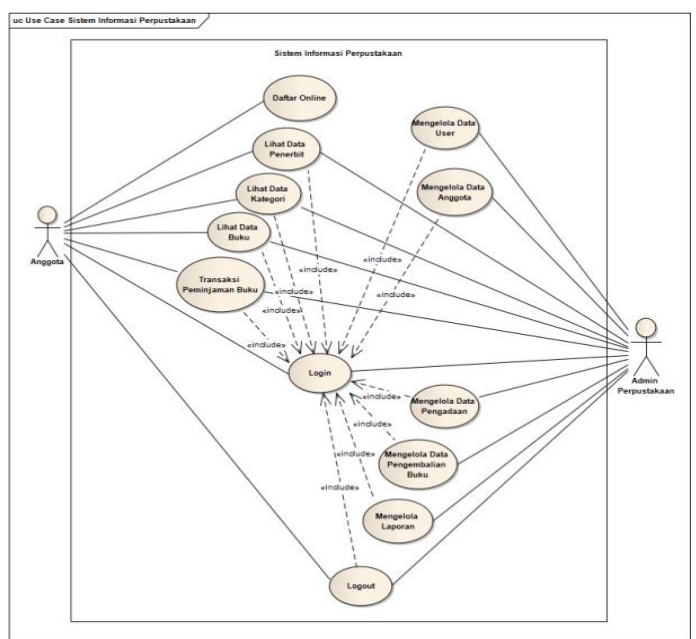

Gambar 1. Use Case Diagram Sistem Informasi Perpustakaan

2. Activity Diagram

a. Activity Diagram Login Anggota

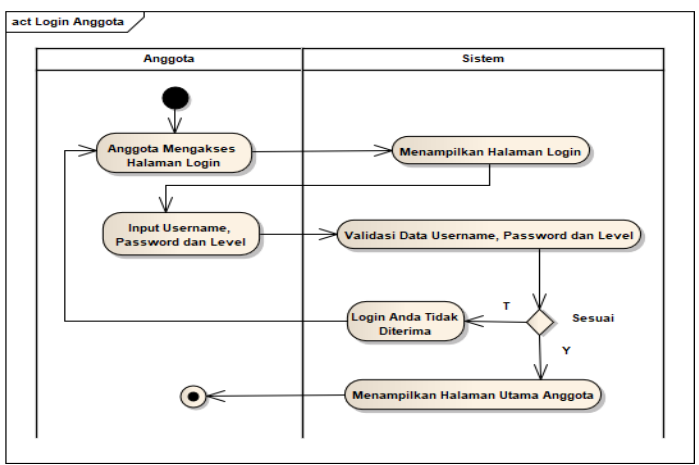

Gambar 2. Activity Diagram Login Anggota b. Activity Diagram Peminjaman Buku

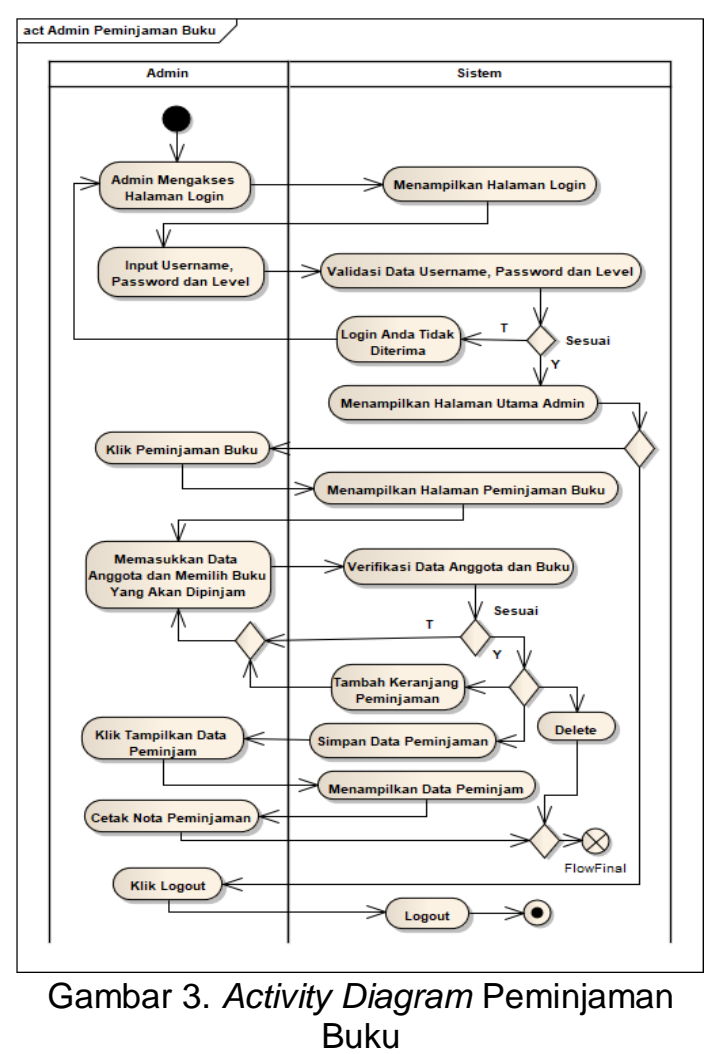

c. Activity Diagram Pengembalian Buku

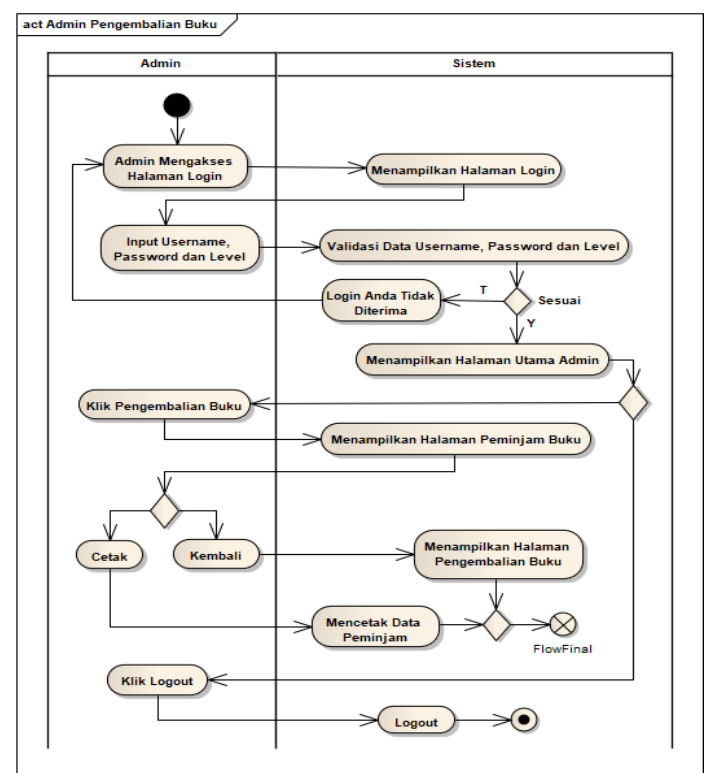

Gambar 4. Activity Diagram Pengembalian Buku

B. Desain Database

1. Entity Relationship Diagram (ERD) 


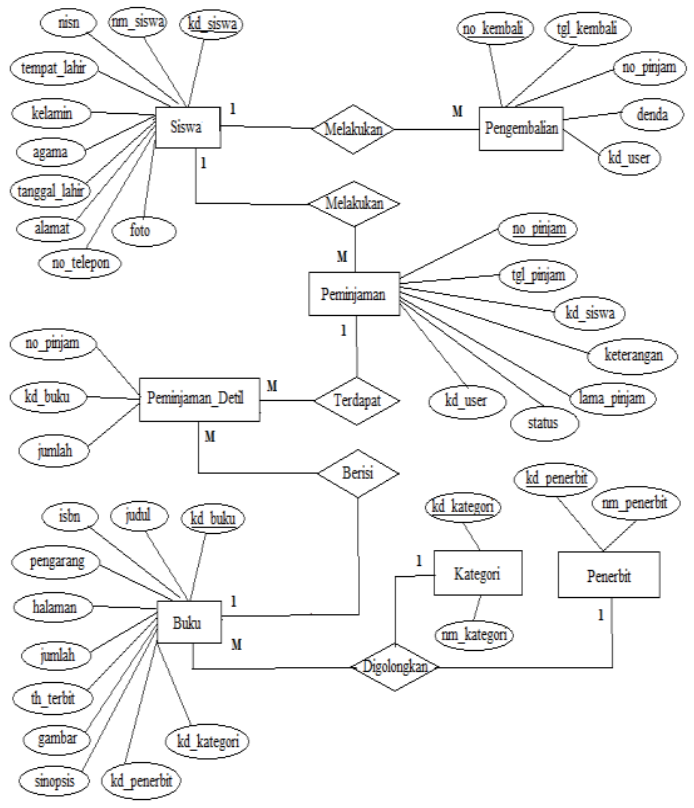

Gambar 5. Entity Relationship Diagram Sistem Informasi Perpustakaan

\section{Logical Record Structure}

\begin{tabular}{|c|c|c|c|}
\hline Do siverma penentit & Vo sinama buku & Vo sicerear peminjaman defil & Do siperma peninjaman \\
\hline I lod denentit: char (3) & I lod buns char(f) & a no pinian: char (b) & I no ginam: char(6) \\
\hline 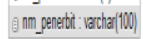 & a just : Iachar(100) & 自 Kd buku c char(5) & a toj jinam: date \\
\hline & 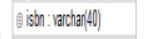 & $\#$ j imlah : int2) & 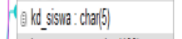 \\
\hline & e pengarang: Iactra(100) & & a keterangan lachar (100) \\
\hline & \# habaran: int(t) & & ; lama pinjam : int(2) \\
\hline & \# jumlah : int(4) & Wo sineman pengadaan & o státus : enum(Priami, Kentali) \\
\hline & (1) th teletit: varchar(4) & in opengablean: char|(a) & a kd user: char[3] \\
\hline & a gambar : Iactia(200) & 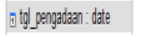 & \\
\hline Vo siperma kategori & 1 isnopsis: text & lo kd bulw : cha(f) & \\
\hline 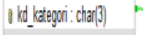 & 4 . Kd penetiti: char(3) & a asa bukn varchar(100) & \\
\hline 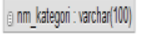 & 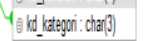 & \# jumlah : int(2) & Do sinerme pengembalian \\
\hline & & (ak keterangan: Iachar|200) & I no kembali c cha/6) \\
\hline & & & 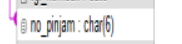 \\
\hline & & V0 sineman siswa & \# denda int 12 ) \\
\hline & & I Kd sisiva: char(5) & G Ko veser: char(3) \\
\hline & & a m sisina : lachar(100) & \\
\hline & & a nisn : Iachar(20) & \\
\hline & & (a) kelarin ccharil| & Wo sipermas user \\
\hline & & (1) agama : archar(20) & $i$ kd usse: char(5) \\
\hline & & 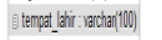 & 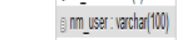 \\
\hline & & a tanogal lair: date & (8 usemane: : Iachia(20) \\
\hline & & (1) alamed : vachar(200) & (8 passuod lachar(20) \\
\hline & & a no telepon: Iacchar(20) & a leal: lacha(20) \\
\hline & & I fito varchar200) & \\
\hline
\end{tabular}

Gambar 6. Logical Record Structure Sistem Informasi Perpustakaan

\section{Arsitektur Perangkat Lunak \\ 1. Component Diagram}

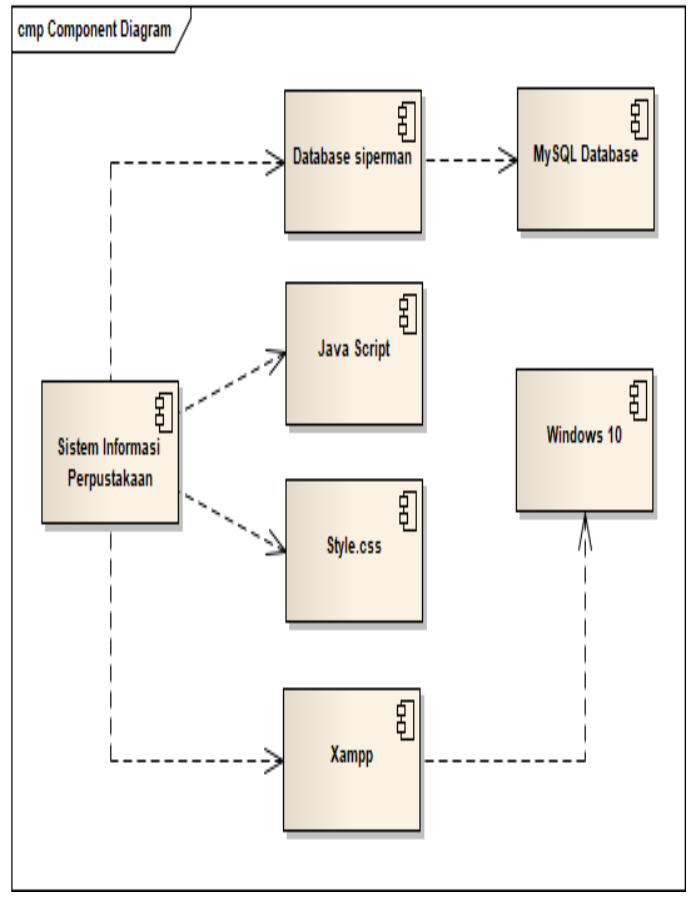

Gambar 7. Component Diagram Sistem Informasi Perpustakaan

\section{Deployment Diagram}

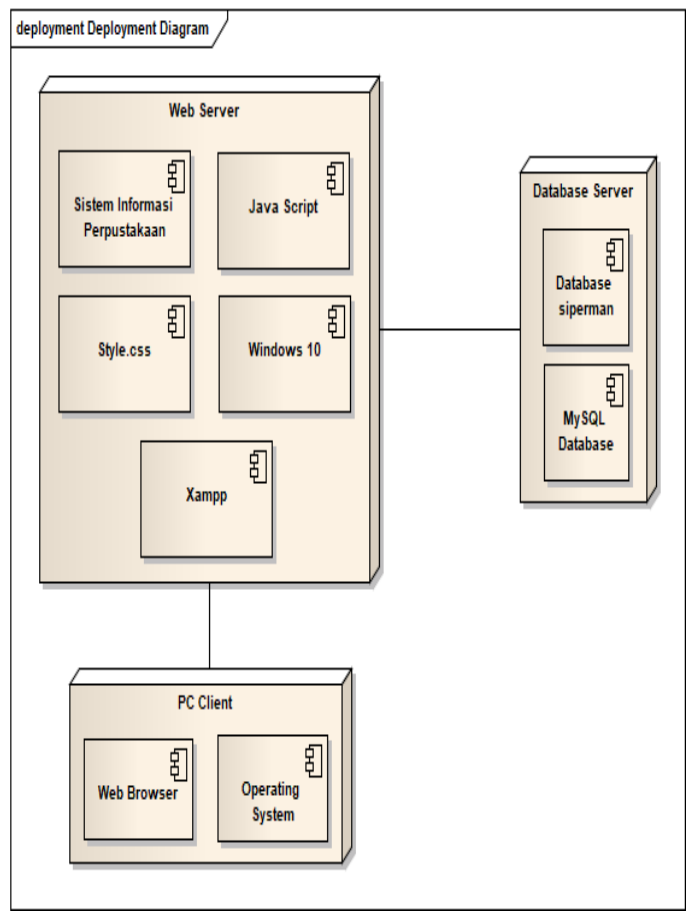

Gambar 8. Deployment Diagram Sistem Informasi Perpustakaan

D. User Interface

1. Halaman Login Admin 


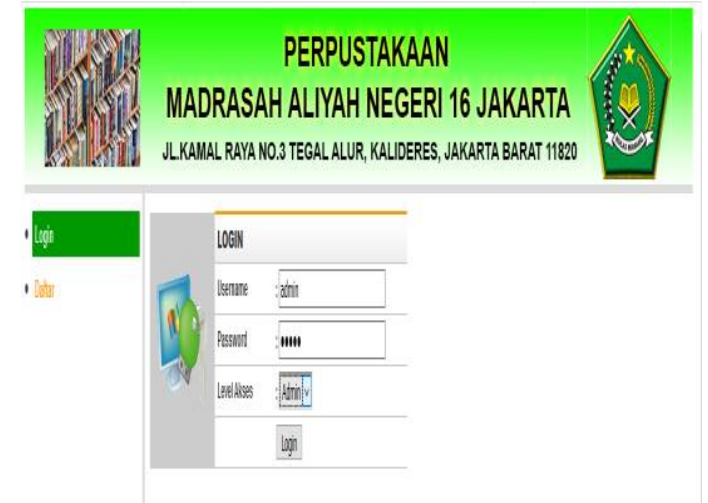

Gambar 9. Login Admin

2. Halaman Utama Admin

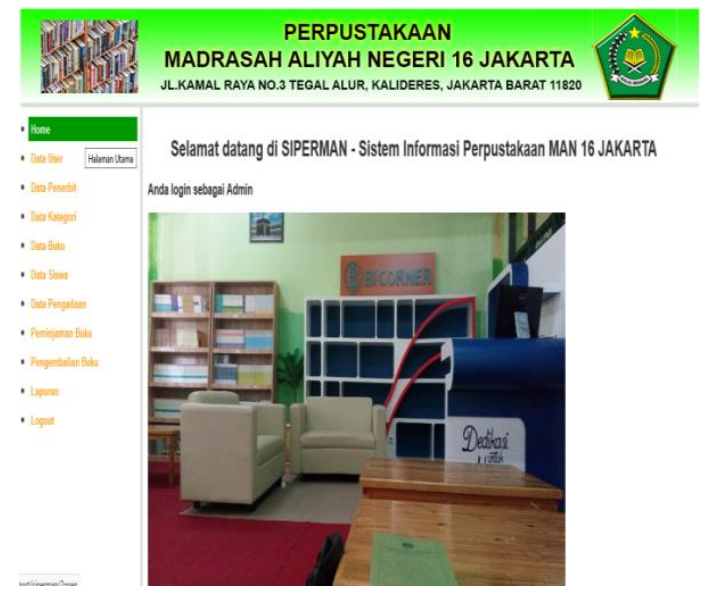

Gambar 10. Halaman Utama Admin

3. Halaman Utama Anggota

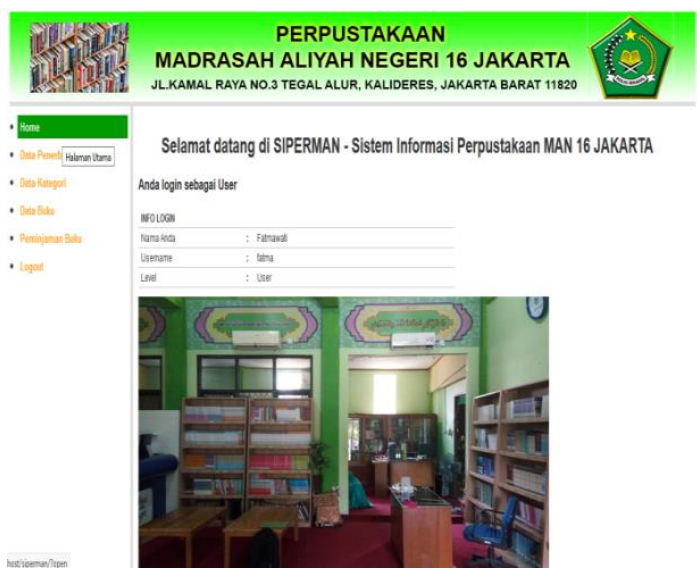

Gambar 11. Halaman Utama Anggota

4. Halaman Admin Kelola Data Buku

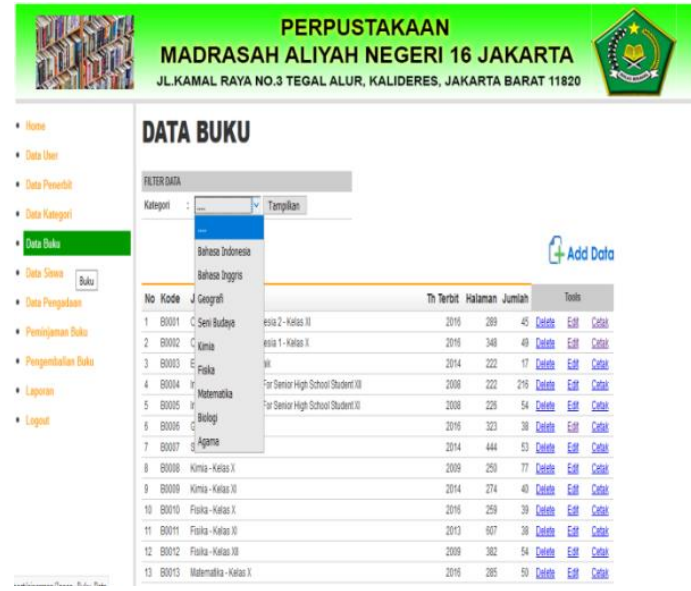

Gambar 12. Halaman Admin Kelola Data Buku

5. Halaman Peminjaman Buku

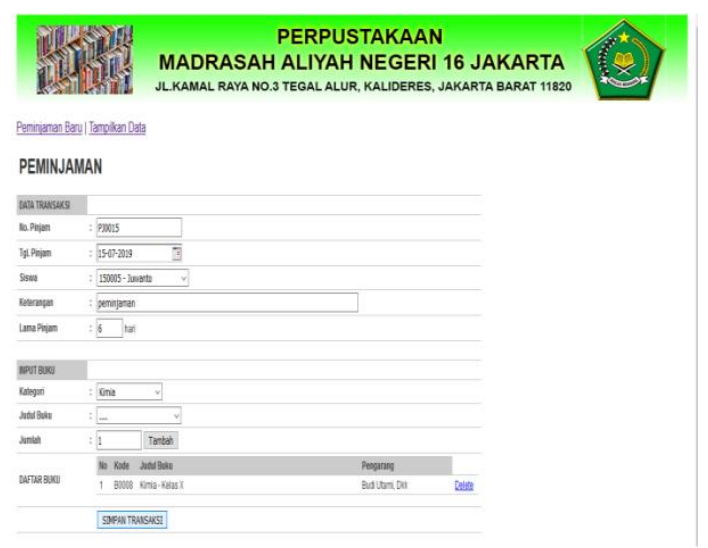

Gambar 13. Halaman Peminjaman Buku

6. Halaman Pengembalian Buku

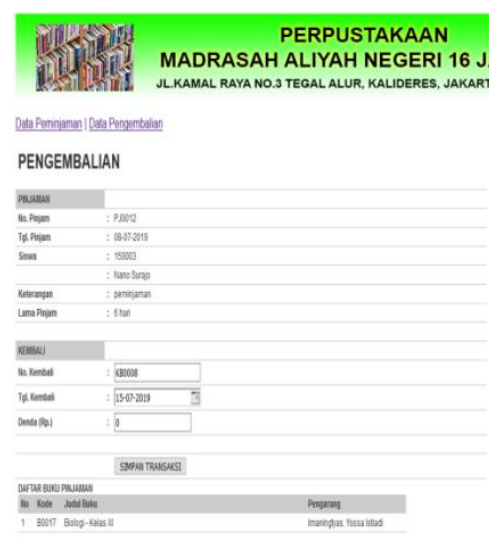

Gambar 14. Halaman Pengembalian Buku 
3.3. Code Generation

$$
\begin{array}{ll}
\text { Code untuk inc.connection.php } \\
<\text { ?php } & \\
\begin{array}{ll}
\text { \$myHost } & =\text { "localhost"; } \\
\text { \$myUser } & =\text { "root"; } \\
\text { \$myPass } & =\text { "'; } \\
\text { \$myDbs } & =\text { "siperman"; } \\
\text { \$koneksidb } & =\text { mysql_connect(\$myHost, } \\
& \text { \$myUser,\$myPass); }
\end{array}
\end{array}
$$

\section{if (! \$koneksidb) \{}

echo "Koneksi MySQL gagal, periksa \} Host/ User/ Password-nya !";

mysql_select_db(\$myDbs) or die ("Database $<$ b $>$ \$myDbs $<$ /b > tidak ditemukan !"); ?>

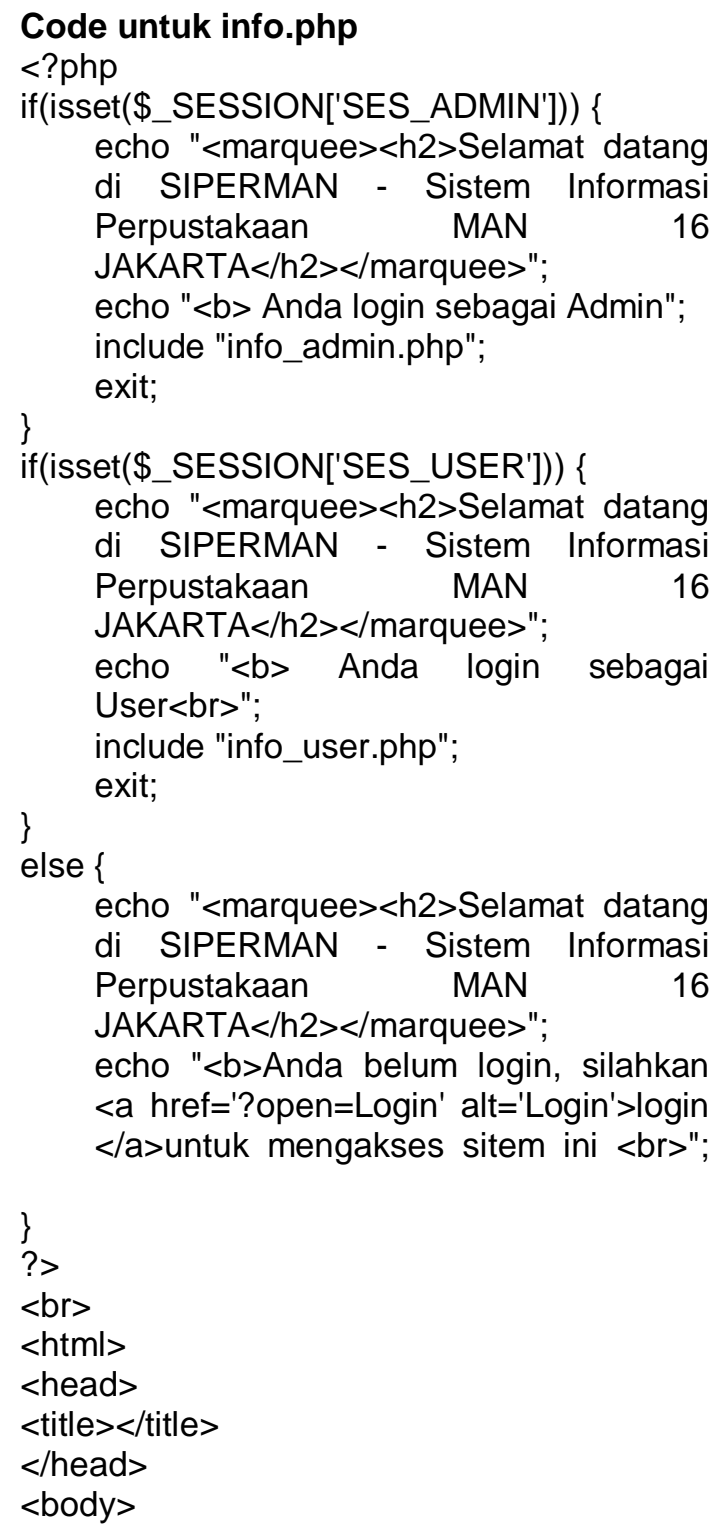

<img src="images/sekolah.jpg" width="800" height="398"/>

$</$ body $>$

$</$ html $>$

\subsection{Testing}

Testing program menggunakan BlackBox Testing. Black-Box Testing yaitu menguji perangkat lunak dari segi spesifikasi fungsional tanpa menguji desain dan kode

\begin{tabular}{|c|c|c|c|c|c|}
\hline $\mathrm{N}_{0}$ & $\begin{array}{l}\text { Skenario } \\
\text { Pengujian }\end{array}$ & Iest Case & $\begin{array}{l}\text { Hasil yang } \\
\text { Diharapkan }\end{array}$ & $\begin{array}{c}\text { Hasil } \\
\text { Pengujian }\end{array}$ & $\begin{array}{c}\text { Kesimpu } \\
\text { lan }\end{array}$ \\
\hline 1 & $\begin{array}{l}\text { Mengkosongkan } \\
\text { sebagian isian } \\
\text { data transalksi } \\
\text { pada inputt data } \\
\text { transalksi } \\
\text { kemudian } \\
\text { mengklik } \\
\text { tombol } \\
\text { "SIMPAN } \\
\text { TRANSAKSI" }\end{array}$ & $\begin{array}{l}\text { No.Pinjam: } \\
\text { (PJo029) } \\
\text { Tol.Pinjam: } \\
\text { (29-07.2019) } \\
\text { Siswa:(Losong) } \\
\text { Keterangan: } \\
\text { (Peminjaman) } \\
\text { Lama Pinjam: } \\
\text { (2 hari) } \\
\text { Kategori: } \\
\text { (kosong) } \\
\text { JudulBuku: } \\
\text { (Losong) } \\
\text { Jumlah: } \\
\text { (1) }\end{array}$ & $\begin{array}{l}\text { Sistem akan menolak } \\
\text { akses simpan data } \\
\text { dan akan } \\
\text { menampillanpesan } \\
\text { "Data Sisma belum } \\
\text { dipilih, silahkanpilih } \\
\text { pada Combo!", } \\
\text { "DAFTAR BUKU } \\
\text { MASIH KOSONG, } \\
\text { Daftar item buku } \\
\text { belum ada yang, } \\
\text { dimasukan minimal } \\
\text { 1 Buku". }\end{array}$ & $\begin{array}{l}\text { Sesuai } \\
\text { harapan }\end{array}$ & Valid \\
\hline 2 & $\begin{array}{l}\text { Menglosongkan } \\
\text { sebagian isian } \\
\text { data transalssi } \\
\text { pada input data } \\
\text { transaksi } \\
\text { kemudian } \\
\text { menglilik } \\
\text { tombol } \\
\text { "Tambah" }\end{array}$ & $\begin{array}{l}\text { No.Pinjam: } \\
\text { (PJ0029) } \\
\text { Tel.Pinjam: } \\
\text { (29-07.2019) } \\
\text { Siswa:(kosong) } \\
\text { Keterangan: } \\
\text { (Peminjaman) } \\
\text { Lama Pinjam: } \\
\text { (2 hari) } \\
\text { Kategori: } \\
\text { (Biologi) } \\
\text { JudulBuku: } \\
\text { (Losong) } \\
\text { Jumlah: } \\
\text { (1) }\end{array}$ & $\begin{array}{l}\text { Sistem akan menolak } \\
\text { akses tambah data } \\
\text { dan akan } \\
\text { menampillkan pesan } \\
\text { "Data Sisma belum } \\
\text { dipilih, harus Anda } \\
\text { pilih dari combo!", } \\
\text { "Data Judul Bulu } \\
\text { belum dipilih harus } \\
\text { Anda pilih dari } \\
\text { combo!". }\end{array}$ & $\begin{array}{c}\text { Sesuai } \\
\text { harapan }\end{array}$ & Valid \\
\hline 3 & $\begin{array}{l}\text { Menginputkan } \\
\text { form data } \\
\text { transalksi } \\
\text { peminjaman } \\
\text { dengan lengkgp, } \\
\text { kemudian } \\
\text { mengklik } \\
\text { tombol } \\
\text { "Tambah". }\end{array}$ & $\begin{array}{l}\text { No.Pinjam: } \\
\text { (PJo029) } \\
\text { Tgl.Pinjam: } \\
\text { (29-07-2019) } \\
\text { Siswa: } \\
\text { (0024797933- } \\
\text { Okttaia Aryani) } \\
\text { Keterangan: } \\
\text { (Peminjaman) } \\
\text { Lama Pinjam: } \\
\text { (2 hari) } \\
\text { Kategori: } \\
\text { (Biologi) } \\
\text { Judul Buku: } \\
\text { (B00017-Biologi } \\
\text { - Kelas XI) }\end{array}$ & $\begin{array}{l}\text { Sistem akan } \\
\text { menyimpan data } \\
\text { buku dan } \\
\text { menampillkarnya } \\
\text { pada DAFTAR } \\
\text { BUKU }\end{array}$ & $\begin{array}{c}\text { Sesuai } \\
\text { harapan }\end{array}$ & Valid \\
\hline
\end{tabular}
program. Pengujian dimaksudkan untuk mengetahui apakah fungsi-fungsi, masukan, dan keluaran dari perangkat lunak sesuai dengan spesifikasi yang dibutuhkan (Rosa \& Shalahuddin, 2015).

Tabel 1. Pengujian Black Box Testing Peminjaman Buku. 


\begin{tabular}{|c|c|c|c|c|c|}
\hline & & $\begin{array}{l}\text { Jumlah: } \\
\text { (1) }\end{array}$ & & & \\
\hline 4 & 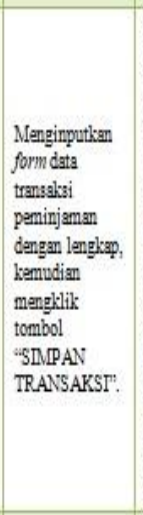 & 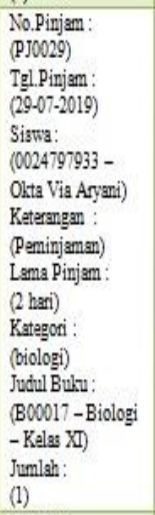 & 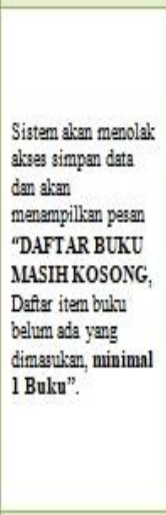 & $\begin{array}{l}\text { Sesua } \\
\text { harapan }\end{array}$ & Valid \\
\hline 5 & 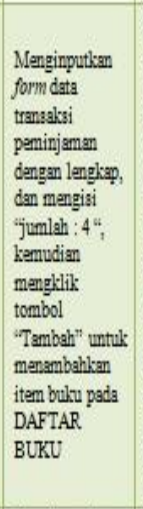 & 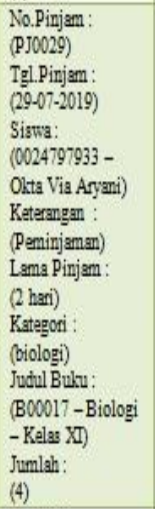 & 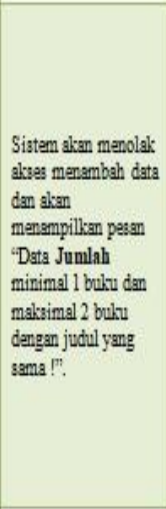 & $\begin{array}{l}\text { Sestua } \\
\text { hargapan }\end{array}$ & Valid \\
\hline 6 & 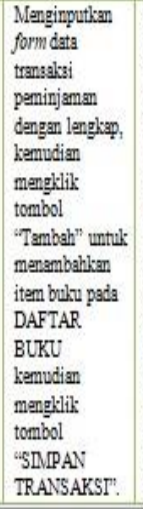 & 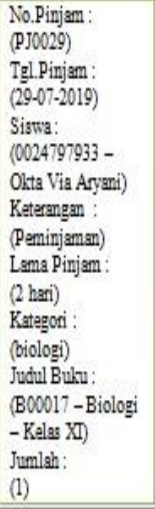 & 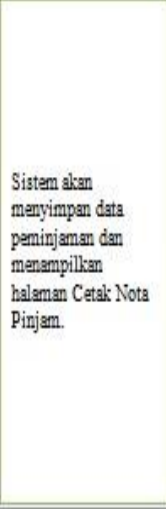 & $\begin{array}{l}\text { Sestua } \\
\text { harapan }\end{array}$ & Valid \\
\hline
\end{tabular}

\section{Kesimpulan}

Dengan adanya sistem terkomputerisasi untuk Sistem Informasi Perpustakaan pada Madrasah Aliyah Negeri 16 Jakarta diharapkan permasalahanpermasalahan yang telah dibahas dapat terselesaikan. Beberapa keuntungan sistem terkomputerisasi ini antara lain :

a. Memberikan kemudahan bagi pengguna sistem informasi perpustakaan dalam proses peminjaman dan pengembalian buku.

b. Memberikan kemudahan pada calon anggota dengan pendaftaran online. c. Mempermudah petugas perpustakaan dalam mengelola data perpustakaan dan laporan.

d. Mengurangi kesalahan pencatatan pada peminjaman dan pengembalian buku.

e. Mempercepat proses pembuatan laporan.

\section{Referensi}

Dari, D. W., Sari, A. O., \& Astrilyana. (2019). Rancang Bangun Aplikasi Perpustakaan Sekolah Berbasis Website. Jurnal IImu Pengetahuan Dan Teknologi Komputer, 4(2), 163-168.

Nugraha, F. (2014). Analisa dan perancangan sistem informasi perpustakaan. Jurnal SIMETRIS, 5(1), 27-32.

Putra, I. P. (2019). Laporan Akhir Penelitian.

Rizki Hendramayana, R., \& Junaidi, A. (2016). Sistem Informasi Perpustakaan SMA Tunas Harapan Jakarta Menggunakan Metode Waterfall. Seminar Nasional IImu Pengetahuan Dan Teknologi Komputer Nusa Mandiri, 185-194.

Rosa, A. S., \& Shalahuddin, M. (2015). Rekayasa Perangkat Lunak Terstruktur dan Berorientasi Objek. Bandung: Informatika.

Sasongko, A. (2015). Rancangan Sistem Informasi Perpustakaan Digital Perguruan Tinggi (Studi Kasus: Perpustakaan AKBID Aisyiyah Pontianak). Jurnal Khatulistiwa Informatika, 3(2), 124-133. 